\title{
Is the treatment for osteochondrolipomas and lipomas the same? Case report and review of the literature on osteochondrolipoma of chest wall
}

\author{
Osteokondrolipom ve lipomların tedavisi aynı mıdır? \\ Göğüs duvarı osteokondrolipomu üzerine olgu sunumu ve literatür incelemesi
}

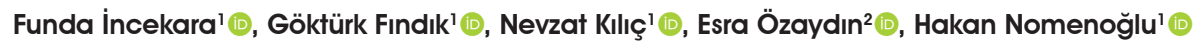

'Department of Thoracic Surgery, Atatürk Chest Diseases and Thoracic Surgery Training and Research Hospital, Ankara, Turkey

${ }^{2}$ Department of Pathology, Atatürk Chest Diseases and Thoracic Surgery Training and Research Hospital, Ankara, Turkey

\begin{abstract}
Lipomas containing bony and chondroid areas are called osteochondrolipomas. Osteochondrolipomas are extremely rare and their treatment is not known exactly. In this article, we report a 41-year-old male patient who had a $45 \mathrm{~mm}$ long subcutaneous mass in the chest wall which was detected 15 years before. When the mass started to grow recently, the patient was admitted to our hospital. Total excision was performed to the mass of the chest wall. According to the histopathological examination of the material, the lesion was an osteochondrolipoma. It might be challenging to diagnose such rare osteochondrolipomas in the tru-cut or small biopsy specimens. Differential diagnosis may be challenging clinically, radiologically, and histopathologically. To our knowledge, this is the fifth case of a totally excised osteochondrolipoma of the chest wall which was reported in the literature.
\end{abstract}

Keywords: Chest wall, en-bloc excision, incisional biopsy, osteochondrolipoma, total excision.

Osteochondrolipoma is an extremely rare type of benign soft tissue tumors. A search in 'PubMed' using the term 'osteochondrolipoma' yielded 10 articles. Kitazawa et al. ${ }^{[1]}$ reviewed 14 osteochondrolipoma cases in their case report published in 2017 and reported the most frequent localization as the maxillofacial region. Chest wall localization is extremely rare and there are only five cases in the entire literature including this study. ${ }^{[2-5]}$ In this article, we discuss osteochondrolipomas that are challenging to diagnose in tru-cut or small biopsy specimens and that lack sufficient data on their treatment. Physicians should keep in mind the osteochondrolipoma as a possible
$\ddot{O} Z$

Kemiksi ve kondroid alanlar içeren lipomlar osteokondrolipom olarak adlandırılır. Osteokondrolipomlar son derece nadirdirler ve tedavileri tam olarak bilinmemektedir. Bu yazıda, gögüus duvarında 15 yıl önce tespit edilen $45 \mathrm{~mm}$ uzunluğunda subkutan kitlesi olan 41 yaşında bir erkek hasta bildirildi. Yakın zaman önce kitle büyümeye başlayınca hasta hastanemize başvurdu. Göğüs duvarındaki kitleye total eksizyon uygulandı. Materyalin histopatolojik incelemesine göre lezyon bir osteokondrolipom idi. Bu nadir osteokondrolipomlara kesici iğne veya küçük biyopsi numunelerinde tanı koyulması zor olabilir. Ayırıcı tanı klinik, radyolojik ve histopatolojik olarak zor olabilir. Bildiğimiz kadarıyla, bu, göğüs duvarının total olarak eksize edilmiş bir osteokondrolipomunun literatürde bildirilen beşinci olgusudur.

Anahtar sözcükler: Göğüs duvarı, en-blok eksizyon, insizyonel biyopsi, osteokondrolipom, total eksizyon.

diagnosis for a well-defined and calcified/ossified subcutaneous mass in the subscapular region.

\section{CASE REPORT}

A 41-year-old male patient admitted to our hospital with a palpable mass on the chest wall which existed for 15 years and had begun to enlarge during the past one year. In physical examination, an approximately $45 \times 25 \mathrm{~mm}$, hard, mobile, and oval-shaped subcutaneous mass was observed in the left subscapular area. Computed tomography (CT) and magnetic resonance imaging (MRI) revealed a well-circumscribed, oval, lobulated mass that measured $45 \mathrm{~mm}$ in the left

Received: June 09, 2019 Accepted: October 12, 2019 Published online: April 22, 2020

Correspondence: Funda İncekara, MD. Atatürk Göğüs Hastalıkları ve Göğüs Cerrahisi Eğitim ve Araştırma Hastanesi Göğüs Cerrahisi Kliniği, 06280 Keçiören, Ankara, Türkiye. Tel: +90 312 - 5677247 e-mail: ozturkdr@hotmail.com 
subscapular area. Computed tomography scan reported that the lesion was predominantly on fat density and contained slightly hyperdense areas, between the muscle plans in the subscapular area. On MRI scan, the tumor mostly showed heterogeneous highsignal intensity on T1-weighted sequences, low-signal intensity on T2-weighted sequences, and heterogeneous high-signal intensity on fat-suppressed T2-weighted sequences. Tumor margin was indistinguishable from the muscle plans at some places in the subscapular area (Figures 1, 2a-c). The lesion had no involvement with the thoracic cavity and did not cause any rib destruction. Surgical intervention was planned for both diagnosis and treatment. For the surgical procedure, the patient was instructed to lie down on the operating table at left lateral decubitus position. An approximately $3 \mathrm{~cm}$ long incision was performed above the ninth rib at left subscapular area. Right after the incision of cutaneous and subcutaneous tissues, the lesion with smooth margins was seen. The lesion had not caused any rib destruction. Total excision was performed by using blunt dissection (Figure 3). The mass was sized $45 \times 25 \times 15 \mathrm{~mm}$ with solid structure and had smooth margins in macroscopical examination (Figure 4). The cut sections of the mass revealed a predominantly yellow, fatty appearance with small white areas. Microscopically, mature adipose tissue mixed with osseous tissue which had bone marrow development in some areas and cartilage tissue was detected under a thin fine bordered fibrous capsule (Figure 5). No cellular atypia was observed and there was no histological evidence of malignancy. The lesion did not have lipoblasts or atypical hyperchromatic spindled cells to suggest liposarcoma. Osseous and cartilage

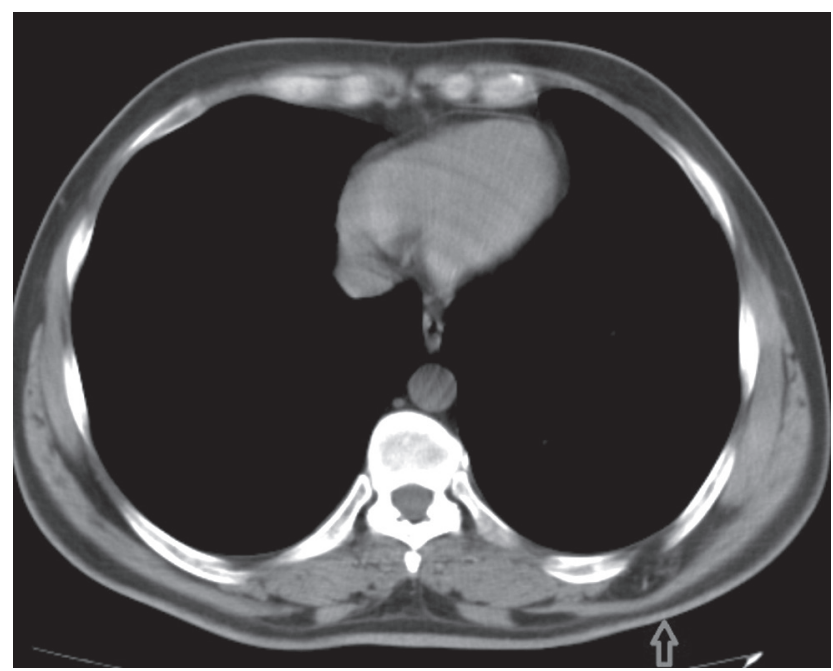

Figure 1. Computed tomography shows a smooth-margined mass in left subscapular region. tissue proportion varied by the level of cross-section. The tumor was diagnosed as osteochondrolipoma with histopathological examination. The patient was discharged on the day after surgery. There was no recurrence or any other complication during the
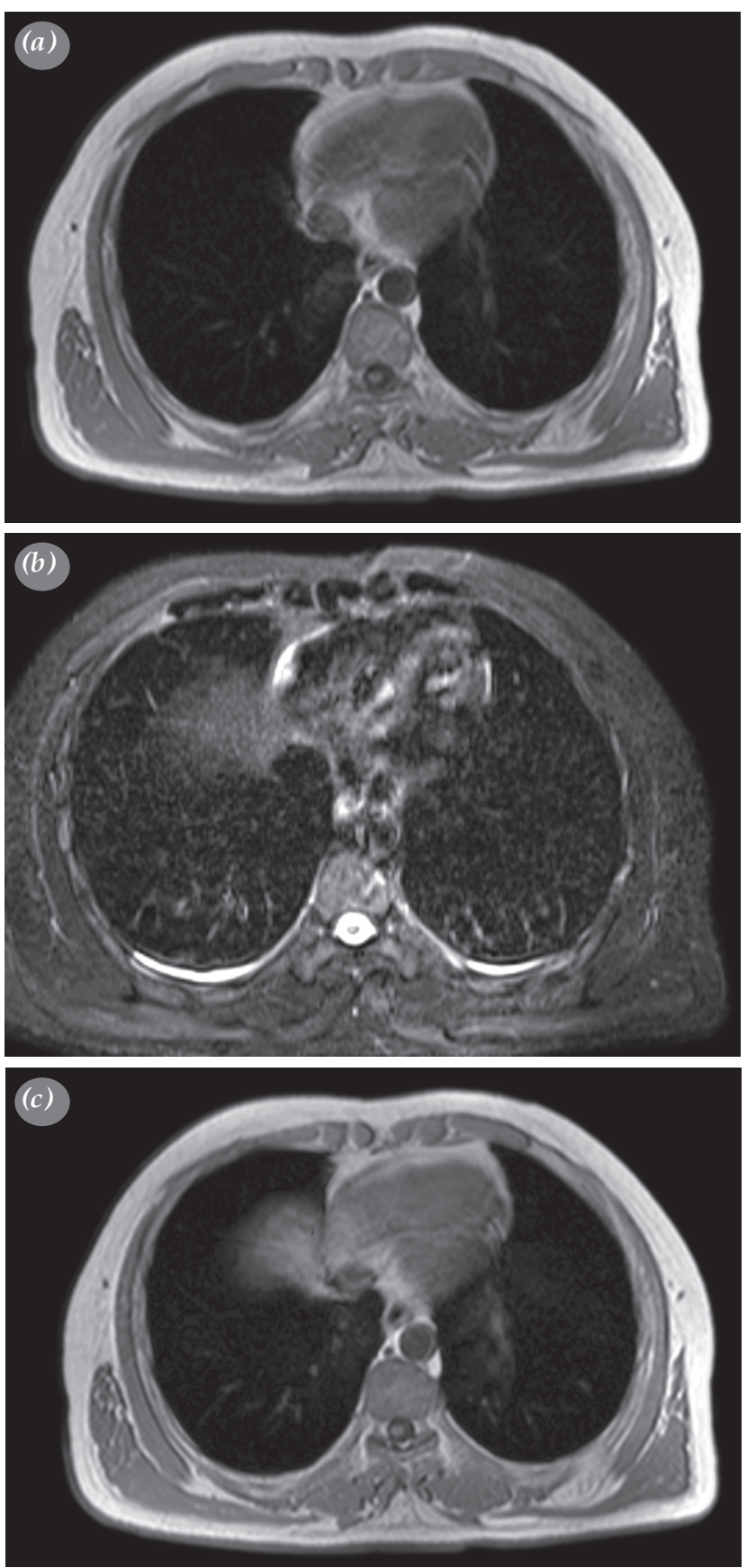

Figure 2. Magnetic resonance imaging shows a smoothmargined mass in left subscapular region. (a) Tumor showed mostly heterogeneous high-signal intensity on T1-weighted sequences, (b) low-signal intensity on T2-weighted sequences, (c) heterogeneous high-signal intensity on fat-suppressed T2-weighted sequences. 


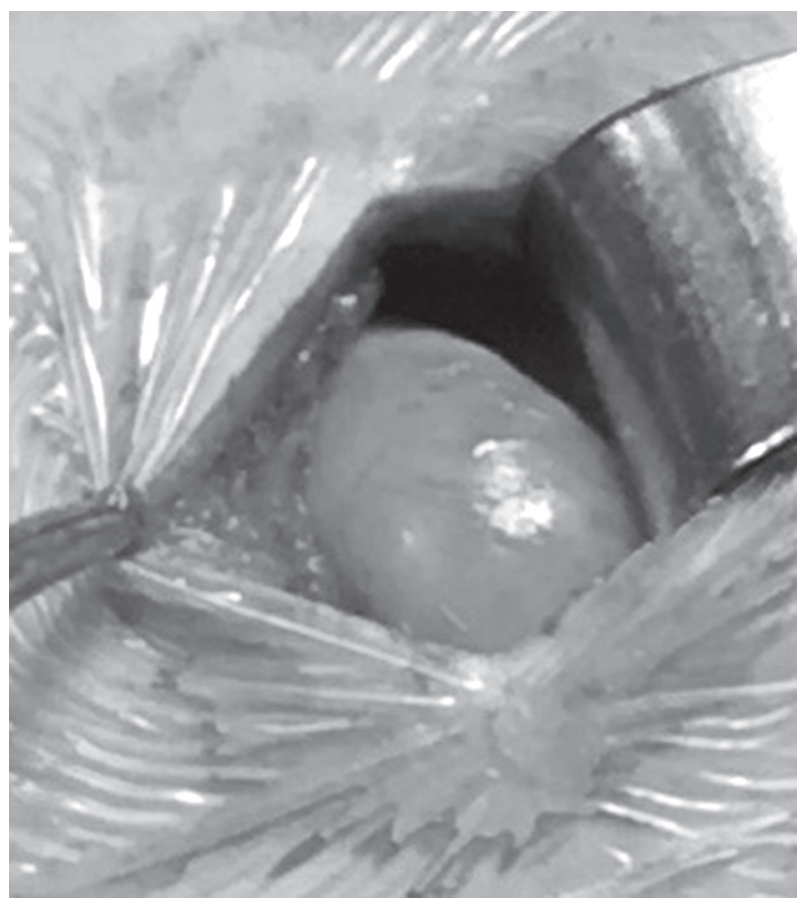

Figure 3. Excision of lesion.

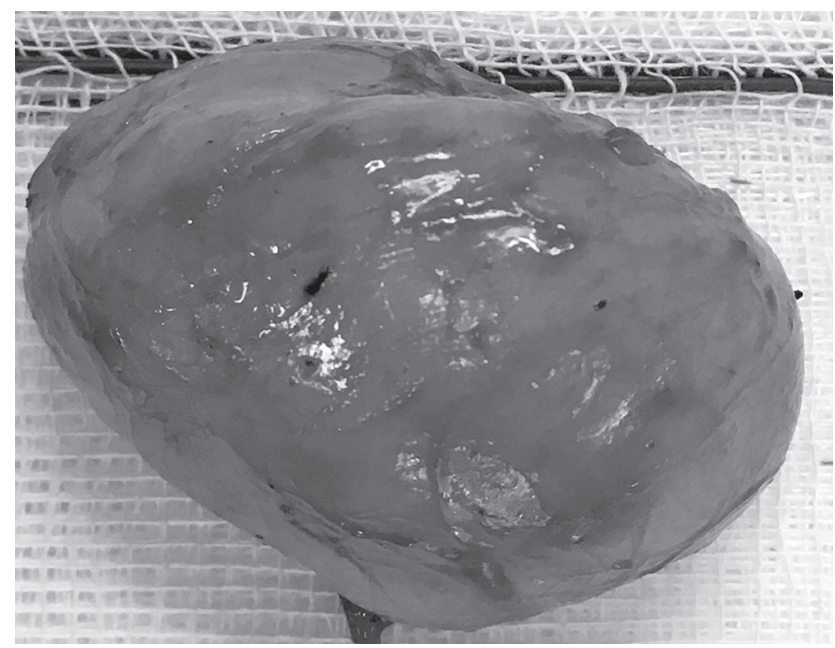

Figure 4. Macroscopic findings of lesion. A $45 \times 25 \times 15 \mathrm{~mm}$ sized, hard, and yellowish mass is seen.

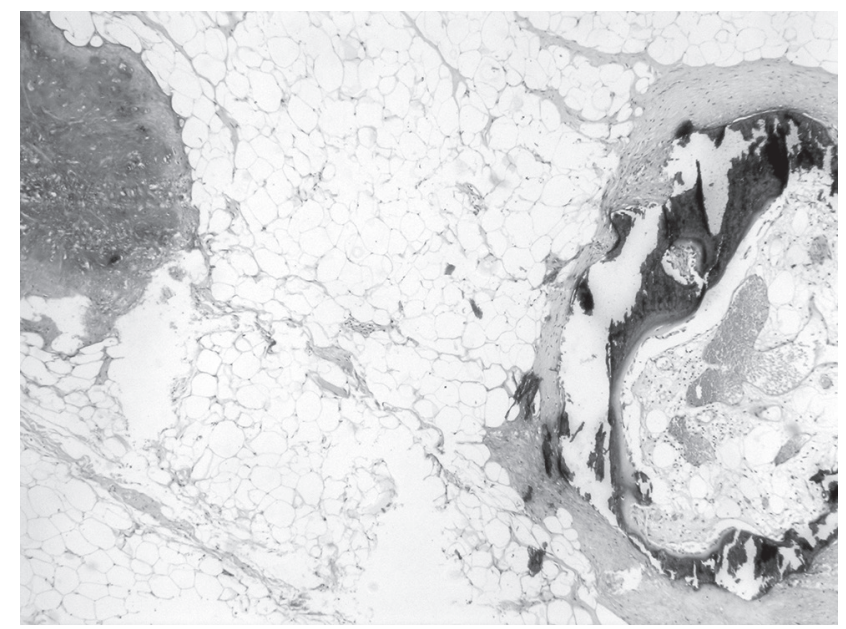

Figure 5. Ossification area that shows bone marrow development besides adipose and cartilage tissues in slides stained with hematoxylin and eosine $(\mathrm{H}-\mathrm{E} \times 100)$.

six-month follow-up. A written informed consent was obtained from the patient.

\section{DISCUSSION}

Osteolipoma terms are used for osseous tissue containing lipoma in soft tissue that has no involvement with any bone. If they have any involvement with a nearby bone, they are called as ossifying parosteal lipoma. Osseous differentiation in lipoma is rare. ${ }^{[6]}$ Osseous and chondroid differentiation is even more rare. If a lipoma contains both osseous and chondroid differentiation, it is called an osteochondrolipoma. Osteochondrolipoma is an extremely rare histological subtype of lipoma. This tumor may occur at almost any site of the body, notably in the maxillofacial region, and be localized subcutaneously (superficial) or profoundly. Chest wall localization is extremely rare. Cases that have been reported including the present case are shown in Table 1. Two of the tumors were localized at subscapular region, one at scapular region, one at left axilla, and the present case was

Table 1. Demographic data of patients and summary of other published reports on osteochondrolipoma of chest wall

\begin{tabular}{clccc}
\hline Case no & Authors & Age/Gender & Location & Size $(\mathrm{cm})$ \\
\hline 1 & Gru and Santa $\mathrm{Cruz}^{[2]}$ & $36 / \mathrm{M}$ & Chest wall, superficial & Small \\
2 & Sunohara et al. ${ }^{[3]}$ & $59 / \mathrm{F}$ & Left axilla, infraspinatus muscle & $79 \times 76 \times 90 \mathrm{~mm}$ \\
3 & Nisio et al. ${ }^{[4]}$ & $49 / \mathrm{M}$ & Left scapular region & $30 \times 30 \mathrm{~mm}$ \\
4 & Panagopoulos et al. ${ }^{[5]}$ & $55 / \mathrm{M}$ & Subscapularis muscle & Unspecified \\
5 & Present study & $41 / \mathrm{M}$ & Left subscapularis region, superficial & $45 \times 25 \times 15 \mathrm{~mm}$ \\
\hline
\end{tabular}


localized at chest wall. There was a predominance of sex in favor of males (four males, one female) and the average patient age was 48 years. The clinical history is usually that of a painless, slow-growing mass. In the first case, ${ }^{[2]}$ the patient admitted with a painless small nodule that was noticed a few months before. In the second case, ${ }^{[3]}$ there was an enlarging painless mass that was noticed five years before. In the third case,$^{[4]}$ the patient had a palpable painless mass that was noticed a month before (Table 1). In the present case, the patient noticed the lesion 15 years before and it began to grow during the past year. Lesion was located superficially. Like many other tumors, the etiology of lipoma and osteochondrolipoma is still uncertain. Moreover, the etiology of cartilage and osseous areas in lipomas is still controversial. There are two main hypotheses for the etiopathogenesis. First suggests that these tumors occur due to the differentiation of adipose tissue-originated stem cells. According to the second hypothesis, these tumors grow as a result of metaplasia of fibroblasts after repetitive trauma, ischemia or metabolic changes. ${ }^{[1]}$ There was no trauma history in the first and third cases. In the second case, act of external forces was held responsible due to the localization of the tumor. There was no trauma history in the present case. Only rheumatoid arthritis was positive as comorbidity. In other cases, no pathogenesis or trauma history was reported. Matsui et al. ${ }^{[7]}$ showed that both fibro-adipose and chondro-osseous components of a tendon lipoma contains high mobility group A2-lipoma preferred partner (HMGA2-LPP) fusion transcript. This situation suggests that HMGA2LPP fusion protein induces both fibroadipogenesis and osteochondrogenesis. Fourth case ${ }^{[5]}$ reported that HMGA2-SETBP1 gene fusion identical to those found in the ordinary lipomas further supports the association both pathogenetically and otherwise between osteochondrolipomas and other lipoma subtypes (Table 1). These studies advocate that these tumors are variants of classic lipomas. Computed tomography is important in the evaluation of osteochondrolipoma and useful for documenting the presence of fatty and osseous elements. ${ }^{[4,8]}$ In the present case, CT clearly demonstrated the presence of surrounding ossification and the association between the tumor and the adjacent bone (Figure 1). Magnetic resonance imaging is generally considered to be the preferred imaging modality for the evaluation of adipocytic tumors. Ossification, calcification, and fibrous connective tissue appear as low-signal intensity areas on all MR pulse sequences. ${ }^{[8-10]}$ In the present case, it was difficult to detect and evaluate the peripheral ossifications by using MRI. The differential diagnosis should include soft-tissue chondromas, extraskeletal osteochondromas, myositis ossificans, ossifying fibromyxoid tumors, chondroid lipomas, and well-differentiated liposarcomas. Since an incisional biopsy samples only a part of the lesion, it can lead to misdiagnosis due to the pleomorphism of osteochondrolipoma; thus histopathological examination of the whole tumor following exenteration is the preferred approach for diagnosis and treatment. If the lesion is too large or if it has adhesions to nearby tissues and if the malignancy potential is high, needle biopsy can be performed before surgery while the lesion cannot be diagnosed completely and specifically with needle biopsy or incisional biopsy. In the second case, ${ }^{[3]}$ authors reported that excisional biopsy was performed and the lesion was found to be benign and contained only benign mature fat cells (Table 1). Following that operation, they excised the mass en bloc. Treatment for osteochondroma is not certain. In the second case, ${ }^{[3]}$ authors indicated that en bloc excision was performed. In the third case, ${ }^{[4]}$ authors reported that the tumor was marginally excised (Table 1). In the present case, a total tumor excision was performed. If the tumor has adhesions between nearby tissues or is suspected to be malignant, en bloc excision may be performed.

In conclusion, our case represents the fifth report of a lipoma with bone and cartilaginous differentiation occurring in chest wall. Given the fact that lipomas can be further subclassified according to specific patterns of differentiation, differential diagnosis may be challenging clinically, radiologically, and histopathologically. Treatment for osteochondrolipomas and lipomas is the same. Total excision should be performed if possible; however, if the mass has malignancy potential, an incisional biopsy should be performed first for diagnosis and then an en bloc excision for treatment.

\section{Declaration of conflicting interests}

The authors declared no conflicts of interest with respect to the authorship and/or publication of this article.

\section{Funding}

The authors received no financial support for the research and/or authorship of this article.

\section{REFERENCES}

1. Kitazawa T, Shiba M. Osteochondrolipoma of the Mandible. Eplasty 2017;17:e35.

2. Gru AA, Santa Cruz DJ. Osteochondrolipoma: a subcutaneous lipoma with chondroid and bone differentiation of the chest wall. J Cutan Pathol 2012;39:461-3. 
3. Sunohara M, Ozawa T, Morimoto K, Tateishi C, Ishii M. Lipoma with bone and cartilage components in the left axilla of a middle-aged woman. Aesthetic Plast Surg 2012;36:1164-7.

4. Nishio J, Ideta S, Iwasaki H, Naito M. Scapular osteochondrolipoma: Imaging features with pathological correlation. Oncol Lett 2013;6:817-20.

5. Panagopoulos I, Gorunova L, Bjerkehagen B, Lobmaier I, Heim S. The recurrent chromosomal translocation $\mathrm{t}(12 ; 18)$ (q14 15;q12 21) causes the fusion gene HMGA2-SETBP1 and HMGA2 expression in lipoma and osteochondrolipoma. Int J Oncol 2015;47:884-90.

6. Tözüm H, Sarıtekin E, Erdem Ş. A rare chest wall tumor: an infiltrating angiolipoma. Turk Gogus Kalp Dama 2014;22:196-8.
7. Matsui Y, Hasegawa T, Kubo T, Goto T, Yukata K, Endo $\mathrm{K}$, et al. Intrapatellar tendon lipoma with chondro-osseous differentiation: detection of HMGA2-LPP fusion gene transcript. J Clin Pathol 2006;59:434-6.

8. Yabe Y, Kumagai J, Koizumi N, Kawamura M, Ono S, Hatori M. Osteolipoma arising adjacent to the sternoclavicular joint. A case report. Ups J Med Sci 2006;111:257-61.

9. Gaskin CM, Helms CA. Lipomas, lipoma variants, and welldifferentiated liposarcomas (atypical lipomas): results of MRI evaluations of 126 consecutive fatty masses. AJR Am J Roentgenol 2004;182:733-9.

10. Minutoli F, Mazziotti S, Gaeta M, Vinci S, Mastroeni M, Blandino A. Ossifying lipoma of the parapharyngeal space: CT and MRI findings. Eur Radiol 2001;11:1818-21. 